\author{
Koncz Katalin
}

\title{
Gender, hatalom és nemzet: eltávolodás a normalitás világától
}

\section{Gender, Power and Nation: Estrangement from the Normal World}

\section{Összefoglalás}

A gender kifejezést, de még inkább a tartalmát, hatalmas zavar és káosz övezi. A tanulmány a gender és a gender tudomány felfogásának történeti fejlődését elemzi. Vizsgálja napjaink gender ideológiájának funkcióját és következményeit. Bemutatja a gender különféle felfogását és hatását a társadalmi szocializációs folyamatra, a nemzet jövőjére. Tudományos értelemben a gender a nők és a férfiak biológiai alapú társadalmi meghatározottsága, ami a szocializáció folyamatában érlelődik. Napjainkban a gender tudományos fogalma és tartalma átértékelődött, a politika szolgálatába állították az érdekeltek. A normalitást átíró gender ideológia nemi identitásként, vagy szexuális orientációként értelmezi, ezzel utat nyit a közel száz féle gender számára. Funkciója, hogy lerombolja a nemzet tartópillérét képező, a nőre és férfira épülő családmodellt. Ezzel az egészséges és életképes nemzet fennmaradását lehetetleníti el.

Journal of Economic Literature (JEL) kódok: A1, I

Kulcsszavak: biológiai nem, társadalmi nem, gender, szocializáció, sztereotípia, feminista tudomány, nőtudomány, gender tudomány, hatalom, nemzet

Prof. Dr. Koncz Katalin, közgazdaságtudományok kandidátusa, ny. egyetemi tanár (Budapesti Corvinus Egyetem) (professor.katalin.koncz@gmail.com). 


\section{Summary}

There is an abnormal chaos concerning the definition and meaning of gender. The study analyses the history of the scientific approach of gender and gender studies, the function and consequences of today's gender ideology. It presents the various definitions of gender as well as the ways in which it affects the socialization process, and the future of the nation. In a scientific sense, gender is the socially and culturally constructed nature of women and men transmitted by the socialization process. Today, the scientific definition and interpretation of gender have been recalibrated, and monopolized by politics for its own purposes. Instead of the ordinary social meaning of women and men, gender ideology interprets it as social identity and sexual behaviour, making way for almost one hundred genders. Its function is to destroy the traditional family model based on woman and man, which represents the pillars of the nation. The consequence of this process is the disintegration of a healthy and viable nation.

\section{Journal of Economic Literature (JEL) codes: Al, I}

Keywords: sex, gender, socialization process, stereotype, feminist studies, women's studies, gender studies, power, nation

\section{BEVEZETÉS}

Zavar, tájékozatlanság, értetlenség, félreértés, félremagyarázás jellemzi a gender kifejezést és a körülötte zajló vitákat. A hazai publicisztikában is nagy vihart kavarnak a gender címszó alatti megnyilvánulások, nélkülözve a fogalom tudományos alapjait, megtévesztve az olvasókat, nézőket. Ismert és felkészületlennek nem mondható vitázók fogalmaznak meg pontatlan, tudománytalan nézeteket. Neves közéleti személyiségek, sőt elemzők is sokféleképpen magyarázzák vagy félremagyarázzák a gender fogalmát, alapvetőnek, avagy éppen mellőzendőnek tekintik társadalmi hatásait, következményét. Pedig az emberek többsége nem tudományos szakfolyóiratokból tájékozódik, hanem média termékekből, hitelesnek vélt „megmondó emberek" véleménye alapján, melyekben alig található tudományosan megalapozott, érthetően megfogalmazott valós tény a genderről, a hallgatók, nézők tájékoztatására. A tudomány pedig nem hallatja a hangját.

\section{A FOGAlOM, mint hatékONy manipulációs ESZKÖZ a hatalom KEZÉBEN}

A pontos fogalomhasználat rendkívül fontos mind a tudományban, mind a hétköznapi emberi kommunikációban. Csak pontos fogalmak alapján kutatható a társadalmi valóság, vázolható a jövő, fogalmazhatók meg hatékony intézkedések. Csak pontos fogalomhasználat alapján valósulhat meg termékeny eszmecsere az emberek közötti mindennapi kommunikációban, érthető meg a másik álláspontja, tisztelhető, becsülhető a másik véleménye. A pontatlanság 
konfliktushoz vezet, káoszt teremt.

Ennél is mélyebb jelentést tulajdonítanak többen a fogalomnak. Idézik például az Illés-együttes híres dalának refrénjét: „A szó veszélyes fegyver” (Illés, 1972). Bogár László napjainkra aktualizálja a fogalmi rendszert: „... a narratívák globális háborúja zajlik.” Sőt a felszín alatti mélyrétegekbe hatolva hatalmi konstrukcióként tételezi: „...minél komplexebbé válik a világ, annál inkább annak a kezében van a főhatalom, aki a szavak fölötti ellenőrzést gyakorolja.” (Bogár, 2020; kiemelés: KK). Fogalmakkal közvetíti a szándékát a hatalom az „alattvalók” felé, a szándékosan elferdített fogalommal a maga érdekében közvetít elferdített valóságot.

A gender fogalom körül olyan sok a zavar, hogy komoly erőfeszítést igényel rendet vágni a fogalmi dzsungelben. Csábító lenne, hogy a politikai diskurzust is bevonjam az elemzésbe, de szándékosan kerülöm ezt az irányultságot. Bár a hétköznapokat és a tudományt is átszövő politikai befolyás kiszűrése nem egyszerű feladat. Nem foglalkozom, sem nem vitázom a gender értelmezés, józan ésszel fel nem fogható, vadhajtásaival (gendersemleges vécék, kisgyermekkori nemváltó műtétek, kislányok öltözőjének használata felnőtt férfiak által, akik nőnek gondolják/vallják magukat, transznemű egyének indulása női versenysportokban, vagy a mesekincsünk átírása és ajánlása a kisgyermekkori szexuális tartalmú érzékenyítésre, stb.). Ezeket a megnyilvánulásokat a normalitás határain kívülre helyezem.

A végletesen eltorzított gender fogalom hatékony eszköz a hatalom kezében, hogy terelje, befolyásolja az embereket miről és miként gondolkozzanak, hogyan cselekedjenek, milyen értékeket kövessenek és adjanak tovább gyermekeiknek, azaz hatékony eszköz a szocializáció folyamatának irányításában ${ }^{1}$ (Koncz, 2020). A gender fogalom tisztába tétele, tudományos értelmezése nélkülözhetetlen a nemi szerepekkel és a nemek közötti munkamegosztással kapcsolatos társadalmi teendők megfogalmazásához, a szocializáció folyamatának megértéséhez, és irányításához. Hozzájárul a mindennapi diskurzus értelmes kereteinek megteremtéséhez.

Mára már kilencvenre vagy ennél is többre tágították az érdekeltek a gender fogalmát, ami alapvetően (szándékoltan) téves alapokra épül. A gender fogalom kiszabadult a tudományos berkekből és politikai célokat szolgál. Politikai érdekek talaján vitázik a jobb és baloldal (bár ma már ez a megkülönböztetés is nélkülözi a valós viszonyokat). A tudományosan értelmezhető gender fogalom elferdítése és politikai célra történő kisajátítása, mindenféle vadhajtásának felkarolása akkor érdemel megkülönböztetett figyelmet, ha szétfeszíti a keresztény kultúránk kereteit, beépül a szocializáció folyamatába, az abban alapvető szerepet játszó oktatási rendszerbe, gyermekeink egészséges fejlődését, a nemzet fennmaradását veszélyezteti, ezzel átlépi a normalitás kereteit - hogy válaszoljak arra a lebegtetett kérdésre, hogy mit is tekintek normalitásnak.

\section{GENDER ${ }^{2}$, MINT A NÖ ÉS A FÉRFi TÁRSADALMi MEghatározotTságA}

Szakírók a gender kifejezést Robert J. Stoller, az UCLA School of Medicine pszichiáter professzorának tulajdonítják. Stoller a szexuális viselkedéssel és perverziókkal foglalkozott, nemi identitásként definiálta a gendert (Stoller, 1984; Green, 2010). A feminista szakirodalom Simon de Beauvoir-hoz köti a gendert, (még csak tartalmában), aki azt társadalmi szerepként 
értelmezi. Beauvoir felfogásában a biológiai nem és a társadalmi nem egymásra épül, a biológiai nem a társadalmi viszonyok közepette szocializálódik, tanul szerepeket, ezzel válik nővé és férfivá az ember (Beauvoir, 1969³). Evelyn Sullerot francia szociológus tágabban értelmezi a gendert, mint társadalmilag meghatározott jelenséget: „A nő igenis nőnek születik, a férfiétól eltérő, beprogramozott fizikai sorssal, és az e különbségekhez kapcsolódó összes pszichológiai és társadalmi következménnyel."- fogalmazza meg egyszerűen (Sullerot, 1983:31). A nőkre és a férfiakra vonatkoztatja a gendert az MTA Társadalomtudományi Kutatóközpontja: „A társadalmi nem fogalma tehát azt jelenti, hogy a biológiai értelemben vett nők és férfiak társadalmilag meghatározott szerepelvárásoknak felelnek meg.” (MTA TTK, é. n.) A két nem társadalmi vonatkozásaként definiálja a gendert az Isztambuli Egyezmény is „...társadalmilag konstruált szerepek, viselkedések, tevékenységek és tulajdonságok, amelyeket egy adott társadalom megfelelőnek tekint a nők és férfiak számára." (Council of Europe I/3, 2011). ${ }^{4}$

\section{AZ EMBER, MINT BIOLÓgIAI ÉS TÁRSADALMI LÉNY}

A feminista szakirodalom a feminizmus második hullámában, a hatvanas években helyezi a nők és férfiak közötti biológiai, társadalmi és gazdasági különbségeket a központi beszédtérbe. A nők esélyegyenlőségének különböző aspektusait vizsgálva, az elődök nyomán mélyrehatóan foglalkozik azzal a kérdéssel, hogy mitől válik nővé a nő, és mennyiben biológiai és menynyiben társadalmi hatások végterméke az emberi nem. Tanulmányok sokasága vizsgálta a nemek biológiai és/vagy társadalmi különbségeit (Sullerot, 1983). Követve a hazai és nemzetközi érdeklődést, ismert hazai tudósokkal, kutatókkal együttműködve egy kötetben mutattuk be a nemi különbségeket különböző tudományok megközelítésében és vizsgáltuk az eltérések biológiai és társadalmi hátterét (Koncz, 1985). Konszenzus alakult ki abban a tekintetben, hogy is-is, biológiai és társadalmi teremtmény az ember. Ebben az összefüggésben vizsgálható a nők és a férfiak megjelenése, tulajdonságai, viselkedése, társadalmi megnyilvánulásai.

A hetvenes, nyolcvanas években a nemek közötti különbségek elemzése a kutatókat is mozgósította. A hazai szakirodalom a női egyenjogúság értelmezési tartományában, a hagyományos családon belüli munkamegosztás kritikájának keretében sokoldalúan foglakozott a gender kérdéssel, mint a nők társadalmi hátrányával és annak forrásával. Széles teret nyert a nemek társadalmi és családon belüli szerepvállalásának elemzése, a nők tömeges munkaerőpiaci integrálódása következtében előálló kettős munkaterhelés magyarázata. Statisztikai adatokra alapozva igazolták, hogy a munkahelyi elfoglaltság és az otthoni feladatok ellátása együttesen a nők férfiakénál nagyobb munkaóra teljesítményében jelenik meg. Ezt jogosan tartották igazságtalannak a feminista szakírók és kétféle irányban tágították a nők lehetőségeinek terét. Egyrészt a férfiak irányába fogalmazták meg követelményként a családon belüli munkamegosztásban való nagyobb részvállalást, másrészt a munkahelyek irányába a kettős szerep összehangolása megteremtésének igényét. Vizsgálták, hogyan és miként alakult ki és maradt fenn a hagyományos családon belüli munkamegosztás, és ebben a biológiai adottságok és a társadalmi befolyások milyen szerepet játszanak. Pro és kontra érvek tömege jelent meg, elsősorban a nemzetközi szakirodalomban, de ébredeztek a hazai kutatók is. Mindez a normalitás keretei között. 


\section{Gender tudomány (Gender studies) a normalitás Jegyében}

Vannak, akik a feminizmust mozgalomként, mások módszerként, esetleg megkülönböztető hangsúllyal interdiszciplináris módszerként, megint mások szemléleti alapállásként vagy tudományként értelmezik. Még kutatói körökben is elterjedt nézet, hogy feminista tudomány nem létezik, a feminizmus mozgalom, amit ki-ki értékelkötelezettsége alapján minősít. Az igényesebb megközelítés megkülönbözteti a feminizmus tudományos (akadémiai, elméleti) és mozgalmi (gyakorlati) áramlatát, melyek kapcsolata országok és korok szerint sokféle változatosságot mutat. A tudomány feltárja a szükségleteket, a problémákat, az okokat és megoldási javaslatokat kínál ${ }^{5}$. A feminizmus, mint mozgalom érdekeket közvetít, kiépíti szervezeti rendszerét, mozgósít a célok megvalósításának érdekében.

A nemek társadalmi helyzetének tudományos vizsgálata különböző szakaszokra osztható, nélkülöz mozgalmi elemeket. A nemzetközi szakirodalom a tudományos és mozgalmi feminizmus rendkíül sokszinü áramlatát kínálja az olvasónak (Rosser, 1992; Tong, 1992). Korántsem a teljesség igényével, egy lehetséges csoportosításban megkülönböztethetjük a különféle irányzatokat eltérő ideológiai gyökereik szerint: az egzisztencialista, az esszencialista, a liberális, a marxista, a szocialista, a posztmodern feminizmust; tudományági kötődése alapján pl. a pszichoanalitikus feminizmust; vallási kötődés alapján pl. a keresztény és az iszlám feminizmust; területi sajátosságok alapján az afro-amerikai feminizmust; a férfiakhoz való viszony szerint a radikálfeminizmust és a leszbikus szeparatizmust. A kilencvenes évek közepén megjelennek a vizsgált területek szerinti feminizmusok is, mint például az ökológiai, a helyhatósági feminizmus (Macey, 1995; Warren, 1994), amelyek besorolhatók a fenti áramlatok valamelyikébe. A hazai túlzó leegyszerűsítés a feminizmust a jogosan elutasított férfiellenes radikálfeminizmussal azonosítja.

A tudományos feminizmus fejlődésének állomásai a feminista tudományok, a nőtudományok és a társadalmi nemek tudománya (feminist studies, women's studies, gender studies). A feminista tudomány (feminist studies) a női nézőpontot jeleníti meg a különböző tudományokban. Elsőként a művészetekben, az irodalomban és a történelemben nyert polgárjogot. Legjelentősebb terméke a feminista filozófia, amely ismeretelméleti talajról vonja kétségbe az eddigi tudományok eredményeinek érvényességét, vagy legalábbis korlátozott érvényűnek tartja azokat. Képviselői azzal érvelnek, hogy az eddigi tudományos közelítések kizárólag az emberiség felét kitevő férfiak által kreált, az ő sajátos nézőpontjukat, tapasztalatukat érvényesítő megismerési kategóriákkal írják le az ennél sokoldalúbb - az emberiség másik felét alkotó nők nézőpontját, értékrendjét és érdekeit is kifejező - valóságot. A feminista filozófia radikális szárnyának képviselői szerint kizárólag a feminista alapállás talaján (tágabban az elnyomottak nézőpontjából) lehet valódi tudományos megismerésre szert tenni.

A nőtudomány (women's studies) értelmezéséről még napjainkban is viták folynak. Megközelítésemben a nőtudomány a nők helyzetét leíró-elemző feminista résztudományok interdiszciplináris tudománnyá szerveződésének állomása. Tartalmazza a világról alkotott női nézeteket, ezért sokan a nőtudományok részének tekintik a nők által művelt tudományokat és művészeteket is. Vizsgálódásának tárgya a női nem, jóllehet elemzései során minden kérdésben akarva-akaratlanul belebotlik a férfiakba. A kétnemű társadalomban a mindkét nemről 
szóló állítás ugyanis csak a másik nemre vonatkoztatott összehasonlítás fényében érvényes. A nőtudomány, jóllehet tudomása van erről, mégis „csak” a női nem társadalmi helyzetének megismerésére koncentrál.

A nőtudomány a kilencvenes évekig szinte kizárólag a nőkre vonatkozott, a férfiak helyzetének elemzése csupán viszonyítási alapként jelent meg, esélyegyenlőségük igénye fel sem merült. A feminizmus - főként annak radikális áramlata - a nők esélyegyenlősége követelésének jegyében férfi érdekeket sért. Ez nem maradhatott visszhang nélkül. A reakciók két irányban teljesedtek ki: az antifeminista férfi mozgalom és a férfi tudományok (men's studies) ${ }^{6}$ kifejlődésének engedtek teret. A hetvenes években Hernádi Miklós a férfiak gyermek-elhelyezési jogáért szállt síkra, az „,anyaszívu” apák” érdekvédelmi szervezeteként létrehozta az Elvált Apák Egyesületét. ${ }^{7}$ Bíró Dávid (1982) nagy vitát kiváltó cikkében a férfi halandóságot a domináns nők térnyerésére vezette vissza. ${ }^{8} 2011$. októberben indult a „Férfihang.hu” antifeminista férfimagazin. Csuzi Attia ötletgazda lapindító elgondolása szerint a magazin olyan író-olvasó közösséggé formálódó portállá válhat, amely a férfi társadalmat érintő és érdeklő társadalmi problémákról is szól. Megfogalmazásában: „,nem csak arról kellene szót ejtenünk, hogy miért érezhetik magukat rosszul a férfiak a feministák szájíze szerinti társadalomban, hanem mindazokról a kérdésekről, amelyek minket, férfiakat, általában foglalkoztatnak.” „...hiánypótló szerepet tölthet be egy ilyen portál, hiszen miközben a nyomtatott és online női lapoknak se szeri se száma, a férfiak családi, jogi, mentálhigiénés, szexuális és életmód problémáinak megoldását csak nagyon kevés magazin tűzi a zászlójára.” A lapban való közlés egyetlen feltétele „az alapjaiban férfiközpontú, avagy férfi-pozitív gondolkodásmód.”9

A társadalmi nemek tudományának (gender studies) megjelenése a feminizmus kritikájaként a hetvenes évek közepén erősödött meg a legkülönbözőbb tudományterületeken, hasznos, értelmes kérdésfelvetéseket és válaszokat helyezve a diskurzus terébe. A két nemet szimbiózisban kezelte, úgy vélte, hogy biológiai és társadalmi okok nyomán minden „nőkérdés” egyben „férfikérdés” is. A nemek közötti viszony elemzésének szánt megkülönböztetett szerepet, mindkét nem hátrányaira érzékenyen rezonált. Értékszempontú közelítésként, az emberi nem (nők és férfiak) egyenjogúságának igényét, képességeinek kifejlesztését és kiteljesítését fogalmazta meg célként. Ebben a kontextusban a nőemancipáció az általános emberi emancipáció része, amely magában foglalja Buda Béla megfogalmazásában „,a férfiak nyomorúságainak felismerését” és felszámolásának szándékát is (Buda, 1985). A nők és férfiak együttes kezelése megjelent a társadalom által közvetített kívánatos szerepfelfogásban az oktatás és kultúra területén, valamint a családon belüli munkamegosztás kritikájában is. A normalitás talaján álló gender tudomány nem tudta (nem akarta?) - feltételezhetően a mozgalmi hatások nyomán - a nők és férfiak esélyegyenlőségét azonos fontossággal kezelni. A nőmozgalom erőteljesebb volt, mint a férfimozgalom, és ideológiailag befolyásolta/meghatározta a gender tudományok nő-elkötelezettségét. A tudományos és a mozgalmi feminizmus még napjainkban is lényegesen erőteljesebb, mint a férfiak társadalmi helyzetét vizsgáló, és a hátrányaik felszámolására szerveződő férfi tudomány és mozgalom. Sőt a normalitás talaján fejlődő gender tudományok új irányt vettek, a politikai genderizmus felé mozdultak el.

A gender tudományban kezdettől szétváltak a gazdasági, közgazdasági irányultságú kutatások, és a nemi identitásalapú kutatások. A gazdasági szemléletet érvényesítő, elismert tu- 
dományos folyóirat a „Gender, Work and Organization” például a nemek (nők és férfiak) munkaerőpiaci helyzetének különböző vetületeit vizsgáló tanulmányokat tesz közzé. „The Wiley Blackwell Encyclopedia of Gender and Sexuality Studies" a nemi identitás, szexuális irányultság kérdéseit vizsgáló egyik elismert folyóirat. Megközelítései teret nyitnak a genderizmus normalitástól eltérő irányzatának.

\section{Tudományos GENDERBől POLITIKAI GENDER (GENDERIZMUS)}

Az ezredfordulót követően vált érzékelhetővé, hogy a politika igyekszik szétfeszíteni a gender tudomány kereteit, módosítani a tudomány által a normalitás jegyében felfogott gendert. Rátelepült a tudományos gender (társadalmi nem) elméletre. „,... jelentéshatalmi szempontból a nemek közötti egyenlőség kifejezés ma már valami egészen mást jelent, mint ahogy mondjuk jó szándékúan és jóhiszeműen gondoltuk volna, amikor maga ez a fogalom, mármint a gender fogalom egyáltalán megjelent.” (Bogár, 2020; kiemelés: KK).

Manapság szinte lehetetlen áttekinteni a gender-ideológia irányzatait és vadhajtásait, erre nem is vállalkozom. Nem csupán a nagyközönség számára értelmezhetetlen, de még a kutatók számára is nagy falat eligazodni útvesztőiben, amely egybemossa, összekeveri a biológiai nem, a társadalmi nem, a társadalmi szerepek, a nemi identitás és a szexuális orientáció jelentését és jelenségeit. A „gender fogalom pályafutását” mutatja be Sípos Írisz (2010) kitűnő tanulmányában: „Gender mint bölcsészeti kategória és eszköz; Gender mint identitás; Gender mint elmélet; Gender mint utópisztikus ideológia; Gender mint a nemiség kultusza; Gender mint az elbizonytalanítás kultúrája." Az elbizonytalanítás megjelenik a konstruktivizmuson alapuló mozgalmak erkölcsi programjában, amely ..., „Az »önkényt « úgy próbálja leleplezni és semlegesíteni, hogy minden mozzanatát - értékeit, normáit, viselkedését - tetszőlegesnek tünteti fel. A nemek közti viszonyban ez - a szerepek semlegesítése ... - a vonzalmak semlegesítése ... az identitás semlegesítése ...” (Sípos, 2010; kiemelés: KK)

Szakítva a gender nő-férfi társadalmi megnyilvánulásaként történő értelmezésével, napjaink nemzetközi szakirodalmában ${ }^{10}$, sokféle defínícióval találkozhatunk. A gender lehet társadalmi identitás, személyiség vagy magatartás jellemző (Chrisler-Lamer, 2016), a nőiesség, férfiasság pszichológiai megnyilvánulása, tanult szerep (LaFont, 2015) és különféle nemi identitások. Chrisler és Lamer azt is állítja, hogy a gender, mint társadalmi identitás általában, de nem szükségszerűen vonatkozik az egyén biológiai nemére. Sőt vannak megközelítések, amelyek a biológiai nemet is társadalmi konstrukcióként értelmezik. ${ }^{11}$ És a zavar csak fokozódik. Így állhat elő a kilencven valahány, vagy mára már ennél is több gender, és lehet eljutni a nő és a férfi („bináris”) felfogástól a genderfluid, gendersemleges fogalmakhoz. Nyomuló politikai szándékot fejez ki a genderizmus kisebbségi kérdéskénti értelmezése, ezzel a kisebbségi jogok irányába történő terelése, a lehetőség megteremtése, hogy emberjogi kérdésként kezeljék. Hazai ismert médiaszereplők sem tudnak mit kezdeni a gender fogalmával. „Én ezt a gender kérdést őszintén szólva marginális problémának tartom. Tehát szerintem ez így nagyon szűk kisebbséget érint. Ezt fölöslegesnek is tartom ..." (Fodor, 2020; kiemelés: KK) Az elemző reflexiója: "... lehet, hogy Magyarországon marginális még a gender kérdés ..." (G. Fodor, 2020; kiemelés: KK.) 
A két nem (nők és férfiak) eltérő külső megjelenésének, testi-lelki különbségeinek biológiai hátterét a DNS molekulák, nemi kromoszómák, nemi hormonok és az ebből fakadó sokféle nemi jellegzetességek alkotják, ami meghatározza reprodukciós szerepüket (Czeizel, 1985; Csaba, 1985). Az MTA Társadalomtudományi Kutatóközpont megfogalmazásában „A biológiai nem fogalma a reprodukcióban betöltött szereppel kapcsolatos (utódok nemzése és szülése)." (MTA TTK, é. n.)

Napjainkban a gender-ideológia a „nem bináris” felfogást követi, miszerint a két véglet (nő és férfi) között számtalan variáció, közbülső állapot létezik, és ezen a kontinuumon elhelyezhetők a legkülönbözőbb szexuális kisebbségek. A genderfluid „elmélet” szerint a nemek közötti biológiai különbségek korántsem élesek, hanem képlékenyek, formálhatók, ami már messzire vezethet, és megalapozza a soktucat gender megjelölését. A gender tehát fluid, képlékeny, nevezik őket nem „bináris embereknek”, „transzneműeknek”, „harmadik nemnek” (Richards, 2016), a kifejezések tárházát is nehéz feltérképezni. Nem tudok állást foglalni abban a kérdésben, hogy a „nem bináris nem” biológiailag milyen mértékben determinált, mert pro és kontra szakirodalmi forrásokat bőven lehetne idézni.

A ,gender" a hazai szakirodalomban a hetvenes években a biológiai nemtől eltérően a társadalmi nemet jelölte, a nőket és a férfiakat a szocializáció során tanult és rögzült jellemzőivel, viselkedésével, szerepeivel jellemezte. A tudományosan igazolt felfogásban a biológiai és a társadalmi nem együttesen alkotja az embert. Ebben a felfogásban értelmezhetetlen a gendert önálló entitásként kezelni, mert nincs társadalmi nem biológiai test nélkül, és a társadalomban szereplő biológia test társadalmilag felruházott jegyek nélkül, mivel nem elszigetelt egyénként, hanem társadalomban élünk. Tehát könnyen belátható, hogy a gender, mint társadalmi nem, önmagában értelmezhetetlen. Csak a fizikai testtel együtt létezik. A biológiailag és a társadalmilag determinált test együttesen jelenik meg, amit a társadalom és az egyén saját értelmezési tartományában érzékel, megél, elhelyez.

A biológiai test meghatározott történelmi, földrajzi, kulturális környezetben szocializálódik, családi, kortárs csoportok és különböző intézmények és szervezetek tagjaként vesz fel szokásokat, szerepeket, őriz tradíciókat, kultúrát. Média közvetítésként éli meg a valóságot. A társadalmi nem (eredeti, tudományos értelemben) több mint társadalmi szerep. Amivé és ahogyan a társadalmi környezet avatja az embert. Ami megnyilvánul az értékbeli elkötelezettségében, a kultúrájában, a céljaiban, a motivációban, a választásaiban, a viszonyulásaiban, a viselkedésében, az elvárásaiban, és sorolhatnánk az emberi lét különféle megnyilvánulási tereit.

Ez a biológiai és társadalmi együttes határozza meg az egyes egyént. Hogy a társadalom elhelyezze struktúrájában ezt az egyéni biológiai-társadalmi testet, a családi nevelés, az oktatás és kultúra együttes hatásaként, jó esetben a biológiai adottságok figyelembevételével, különféle szerepekkel ruházza fel. Felépíti sztereotípiáit, megrajzolja a férfiasság (maszkulinitás), nőiesség (feminitás) normáit, amit az intézményrendszerén keresztül közvetít az egyének felé követelményként. Ezzel befolyásolja, irányítja a kívánatosnak tartott szerepmodellt, amely akkor életképes, ha a nemzet fennmaradását, fizikai, és lelki egészségének megőrzését szolgálja. 
Mivel a szocializáció társadalmi folyamat, a társadalom, a nemzet joga és kötelessége eldönteni, hogy milyen értékeket kíván átörökíteni. Nem az egyéneké és nem különböző érdekeket követő lobbi csoportoké, nem globalista hatalmi csoportosulásoké.

Az egyén használja, értelmezi, nemi identitásként dekódolja biológiai-társadalmi testét. Követi szexuális és sokféle egyéb orientációját (kulturális érdeklődés, pályaválasztás stb.), elkötelezettségét. Az egyéni választás nyomán kirajzolódnak a különböző szexuális orientációt követő rétegek, egyéni életérzést, törekvést, motivációt követve, amelynek megélése alapvető emberi joguk. Ez az egyéni interpretáció jelenik meg gender fogalomként napjaink gender-ideológiájában, a genderizmusban.

A nemi identitás (az érzés, hogy milyen neműnek véli magát az ember) alapesetben egyezik a születéskori nemmel. A nő nőnek, a férfi férfinak érzi magát. Azt a jelenséget, amikor az egyén nemi identitása eltér a születéskori nemétől nemi diszfóriának (korábban nemi identitászavarnak) nevezi a szakirodalom. ${ }^{12}$ A nemi identitás kialakulásának okára és folyamatára különböző elgondolások vannak. Ebben az esetben is tetten érhető a biológiai és társadalmi determináció elmélete. „A biológiai háttér magyarázatában elterjedt egyik hipotézis szerint (developmental mismatch) a méhben a nemi szervek fejlődése és az agy szexuális differenciálódása eltérő ütemben zajlik, és ez lehetővé teszi, hogy eltérő irányba forduljon a test és az agy.” (Dr. K.A., 2018) ${ }^{13}$ A társadalmi okság talaján állók szerint a fiúk és lányok viselkedése azért különbözik, mert „eltérő szociális normák szerint neveljük őket” (u.ott.). A tudomány ebben a kérdésben sem ad kielégítő támpontot. „..... gender diszfória biológiai gyökereinek megértése még messze van, és mint az az emberi tapasztalat számos más területén is jellemző, a nemi identitást meghatározó neurális mechanizmusok továbbra is rejtélyesek, azonban a tudomány már elkezdett kapaszkodókat találni a megértéséhez.” (u.ott; kiemelések: KK.) Valószínű, hogy a nemi identitás mindkét irányzat leegyszerűsítő álláspontját meghaladva, öszszetett jelenség, ami biológiai, pszichológiai és szociális hatóerők kombinációja következtében alakul ki. A biológiai test a társadalmi szocializáció folyamatában éli meg nemi azonosulását, ami a gender (mint társadalmi nem) egyik vetülete, de nem azonos a genderrel.

A gender-ideológia a gendert (amely tudományos értelemben a biológiai nem társadalmi megnyilvánulása) napjainkban nemi identitásként vagy szexuális orientációként értelmezi. Ekként fogalmaz az MTA Társadalomtudományi Kutatóközpontja is: „Vannak olyan csoportok is, amelyek tagjai esetében a társadalmi nem fogalma nem mindig a férfi-nő kettősségen alapul, akiknek nemi identitása vagy szexuális irányultsága eltér ettől” (MTA TTK, é. n.). Nemi identitásként írja le a gendert a Transznemű Egyesület is: „Vannak, akik többneműek, vagyis több mint egy nemi identitással rendelkeznek (ez lehet, férfi, nő vagy egyéb) akár egy időben is vagy ez változik náluk. Például: kétnemű, akinek két egymástól elkülönülő nemi identitása van (bigender), háromnemű, akinek három egymástól elkülönülő nemi identitása van (trigender), többnemű, akinek több egymástól elkülönülő nemi identitása van (polygender)." (Transvanilla, é. n.). További gendereket fogalmaznak meg, nem idézve hosszabban: nemtelen (agender), nem nélküli (gender neutral), változó nem (gender fluid), harmadik nem (third gender), köztes nemü (intergender), stb.

Ha a genderizmus a nemi identitást, a szexuális orientációt értelmezi genderként (társadalmi nem), akkor azt a szocializáció eredményeként tételezi. A nem bináris nem társadal- 
mi megnyilvánulásaként. A gender ideológia megfosztja a gendert, mint társadalmi nemet tudományos alapjától, hogy a politika eszközrendszerévé tegye. [Ismételjük: „A társadalmi nem fogalma azt jelenti, hogy a biológiai értelemben vett nők és férfiak társadalmilag meghatározott szerepelvárásoknak felelnek meg.” (MTA TTK, é. n.)] A gender fogalom nemi identitáskénti értelmezése tág teret nyit kiszélesítésének, „,a nemi identitás tehát nem a férfi és a nő egymástól különböző, ugyanakkor egymást kiegészítő lényegbeli adottságán alapszik, hanem egyedek egymástól eltérő és számos variációban létező önképén és nem utolsósorban szexuális preferenciáján.” (Sípos, 2010.) Bőséges anyagi erőforrásokra és intézményi háttérre épülő erőteljes érdekérvényesítő képesség és propaganda támogatja a szocializációs folyamatba benyomuló gender-ideológiát.

Ebben a fogalmi forgatagban megválaszolatlan kérdés, hogy a biológiailag „,nem bináris” test milyen társadalmi szerepet tölt be? Mert társadalmi szerep nélkül nem létezik biológiai test. Miközben a „nem bináris” test megéli saját, a többségtől eltérő nemiségét, a többségi társadalmi normákkal való azonosulás hiányában, akarva, akaratlanul rést nyit a hagyományos nemi szerepekre épülő szocializációs folyamatban. Amit a hagyományos családi értékek szétrombolására, a népesség fejlődésének korlátozására, a nemzet fennmaradásának akadályozására felhasznál az ebben érdekelt hatalom. Hogy normává tegye a „nem bináris” és az ehhez tapasztott, nemi identitásként interpretált társadalmi konstrukciót. Ezáltal válnak a jelentős társadalmi támogatottság hiányában sérülékeny „nem-bináris” emberek a politika könnyu játékszerévé. Napjainkban vált nyilvánvalóvá a gender ideológiát felhasználó hatalom törekvése, miután teljes nyíltsággal helyet követel magának a gyermekek nevelésében, oktatásában is. A jövő generáció ,érzékenyítésében”.

A gender semlegesség a nő-férfi szerepfelfogással szemben a gender ideológia szerves része a jelenlegi hazai és nemzetközi propagandában. A gender semleges nevelés szerint a gyerek, születéskori biológiai nemétől függetlenül, majd eldönti, hogy mi akar lenni. A gender semleges nevelés a „hagyományos” sztereotípiák szerinti nevelés felszámolását szorgalmazza. Bár számomra ennek gyakorlati kivitelezése felfoghatatlan, annyit az előzmény törekvésekből (nemi sztereotípiák felszámolása az iskolai tankönyvekből) már értek, hogy a kislányok ne csak babákkal játszanak, a kisfiúk pedig ne csak autókkal, vagy szerelhető játékokkal. Bár normális esetben ezt senki nem tiltja, és az óvodákban az egymással játszó gyerekek szívesen használják a másik játékát is, megfigyelhető, hogy a kisgyerekek ösztönösen a biológiai nemüknek megfelelő játékokhoz fordulnak nagyobb gyakorisággal. A kislányok ringatják, pelenkázzák, nyugtatják a babákat, a kisfiúk pedig szétszedik a szerkezetet, a belsejét kívánják megtekinteni. Anélkül, hogy erre bárki kényszerítené őket. Arra nem találtam szakirodalmat, hogy a nembináris gyermek (ha van ilyen) ösztönösen milyen játékokhoz nyúl?

A gender semleges elmélet a hagyományos szerepek felszámolását célozza meg, ami a komplementer, sztereotípiának elkönyvelt felnőtt szerepek szétzilálására irányul. Kárt okoz a nemzet számára a folyamat megértésének hiánya. Gerő András, a Habsburg Történeti Intézet igazgatója, felteszi a kérdést: „Mi ezzel a probléma?” (mármint a gender semleges neveléssel). „Egy országban, ha tételezünk egy társadalmat, és azt, hogy a társadalom bizonyos szabadságjogokat biztosít, hát hadd legyen az már a magánjogok birodalmába tartozó, hogy ki hogyan akarja úgymond nevelni a gyerekét. Van, aki rasszistának neveli a gyermekét, van, 
aki gender semlegesen, van, aki ...”. „... Ezek ellen lehet társadalmilag valami diszkussziót folytatni, hogy mit tartunk helyesnek, és mit nem, de az államnak ehhez nincs köze.” „... hagyni kell az embereket élni, úgy ahogy akarnak.” (Gerő, 2020; kiemelés: KK)

\section{A sZOGIALIZÁció SZEREPE A NEMI SZEREPEK KIALAKULÁSÁbAN}

A szocializáció a társadalom ${ }^{14}$, a nemzet, annak egyes rétegei, csoportjai értékeinek, viselkedési szabályainak, normáinak elsajátítására irányuló folyamat. A szocializáció útján válnak az egyének a társadalom, a nemzet, és annak részegységei tagjává. Az egyes alcsoportok (társadalmi rétegek, kulturális, vallási, politikai közösségek) normarendszere és az azt közvetítő szocializáció folyamata közötti eltérések konfliktusokhoz vezethetnek. Egy nemzet szocializációs folyamata annál eredményesebb, minél nagyobb összhang van az egyes alcsoportok normái és céljai, valamint az azt közvetítő szocializációs alrendszerek között.

A kívánatosnak tartott normák a célrendszerből vezethetők le. (A továbbiakban csak a nemzeti szinttel foglalkozom.) Mi a nemzet célja? Mint egésznek és mint tagjainak a fennmaradása és fejlődése, gazdagabbá válása fizikai, szellemi, lelki értelemben. A fiziológiai, pszichológiai és kulturális normarendszer legfőbb közvetítő közege a család és a társadalmi intézményrendszerek (gyermekintézmények, oktatási és kulturális rendszer, egészségügy, szociális gondoskodás), valamint az ezeket megalapozó gazdaság. A szocializáció a családi, iskolai nevelés és a munkamegosztás gyakorlatában, szervezeti tagozódásában kialakult értékeket, szerepmodelleket örökíti át. Mélyen a társadalom sejtjeibe ivódott tradíciók szabályozzák, hogy mit kell, és mit illik tennie a társadalom szereplőinek. ${ }^{15}$

A nemzet fennmaradásának és fejlődésének alapja a gyarapodó népesség fizikai, szellemi és lelki egészségének biztosítása, ami a születések és halálozások dinamikájára épül. A népesség gyarapítására, reprodukciójára a nő és férfi közössége képes. ${ }^{16}$ A nemzet fennmaradásának és fejlődésének követelménye ebből következően a nőnek és a férfinak tulajdonított szerepek átörökítése. Ebben a folyamatban a gyermekkori szerepgyakorlásnak igen fontos funkciója van: a felnőtt szerep ellátására készít fel. A nemzet egészséges fejlődésének követelménye a gyermekkori szocializáció női és férfi szerepekre történő felkészítése, mert ez biztosítja a nemzet fennmaradását és fejlődését. A nemek társadalmi szerepei a nemzet fejlődésével változó sztereotípiaként rögzülnek, de a biológiai alapjuk továbbra is a nő és férfi egysége. Ezért a „társadalmilag kreált nemi sztereotípiák” felszámolásának követelése tudományosan nem igazolható felfogás, sanda politikai szándékot közvetít.

\section{SZTEREOTÍPIA a sZereptanulás SZOLGÁlatában}

A sztereotípia tudományos megközelítésben „információ-feldolgozási paradigma”, semleges fogalom, „racionális kategória”, absztrakciós modell, amely segíti az információk feldolgozását a közös elemek, a közös sajátosságok csoportosítása és kategorizálása útján - mondja a kutató (Hunyadi, 2001). Ennek hiányában minden egyes egyént meg kellene vizsgálni, hogy tulajdonságai leírhatók legyenek. Nem a sztereotípia a káros, hanem a sztereotípiákhoz, mint társadalmi-kulturális szerepekhez tapadó hátrányos következmények a nem kívánatosak. Vi- 
lágosabban: nem az a probléma, ha a családorientált férfi vagy nő, vagy mindkettő sztereotíp viselkedésként a családgondozásnak kívánja életét szentelni, hanem hogy ez a választás hátrányos helyzetbe hozza őket.

Nagyon fontos sokszorosan aláhúzni azt a tényt, hogy nők és férfiak annyifélék, ahányan vannak. A sztereotípiák a nők és a férfiak társadalmi csoportjára, tagjaik nagyobb hányadára vagy statisztikai átlagára jellemzők, amitől az egyes egyének lényegesen különbözhetnek és különböznek. A csoport tagjainak többségére, vagy az átlagra érvényes tulajdonságok, tanult viselkedésminták sztereotípiákká rögzülnek, és meghatározzák a nőkről és a férfiakról alkotott nézeteket, biztosítva a sztereotípiák újratermelődésének közegét. A nők társadalmi helyzetének javítását szorgalmazó mozgalmak gyakran hangsúlyozzák a sztereotípiák felszámolásának igényét, miközben azáltal, hogy a nők társadalmi csoportját hátrányos helyzetű rétegnek tekintik, maguk is sztereotípiák szerint gondolkodnak. Ezt a kettős mércét, váltakozó nézőpontot nevezem sztereotípia-csapdának, amin felülemelkedni csak az egyéni adottságok szintjén lehet. A nem kívánatos sztereotípiákat (pl. állásinterjú esetében az egyének csoportjellemzőként történő megítélése) úgy lehet elkerülni, ha az egyénekről szóló döntések során sajátos helyzetüket, körülményeiket, adottságaikat mérlegelik a döntéshozók, és nem statisztikai tömegként kezelik őket.

A komplementer, egymást kiegészítő szerepmodellnek a továbbélése nagyon fontos társadalmi funkciót tölt be, a jövóbeni családi szerepekre készíti fel a generációkat. Hogy ezeknek a hagyományos nemi szerepeknek a határai oldódnak, bizonyítja a mai fiatal apák gyermekgondozási részvállalása. A nagy kérdés, hogy meddig lazíthatók (egyesek szerint felszámolandók) a „hagyományos nemi szerepek”? És az új - de meg nem fogalmazott - konstrukciónak mi a funkciója? Kik lesznek a nyertesek vagy vesztesek? „A tudomány még nem adott választ arra a kérdésre, hogy meddig érdemes és szabad a hagyományos komplementer szerepeken lazítani, és ez mikor vezet az emberi képességek, készségek gazdagításához, és mikor vet fel identitás problémát - a maga káros következményeivel együtt. Az bizonyosnak tűnik, hogy az apák nagyobb mértékű bevonása a gyermeknevelésbe az érintettek mindegyikének érdekeit szolgálja, amit a fiatal apák gyakorolnak is. A gyerekek egészséges fejlődése szempontjából fontos, hogy a férfiak nagyobb részt vállaljanak a gyerekek szocializációs folyamatának teljes spektrumában, amiből jelenleg - a munkaerőpiac szegregáltsága miatt is - kimaradnak”. A férfi (apa és tanár) minta hiánya a szocializáció folyamatában mindkét nemű gyermek szerepkészletének tartományát szűkíti (Buda, 1985). A gyerekek (fiúk és lányok) nem sajátíthatják el a családépítéshez nélkülözhetetlen nemi szerepeket, ami felnőtt korukban szerepkonfliktushoz vezethet. Nem túlzó a következtetés, hogy (egyebek mellett) ez is szerepet játszik a szingli lét terjedésében.

A társadalmi munkamegosztás változásából eredő szerepátrendeződés, a nők tömeges önkéntes és kényszerű - beáramlása a munkaerőpiacra, a férfiak önkéntes és kényszeru” részvállalása a családi-háztartási feladatok ellátásában szerepbizonytalanságot okoz férfiak és nők körében egyaránt. A hagyományos szerepfelosztás gazdasági alapja megingott, miközben az új szerepmegosztás társadalmi feltételrendszere még nem épült ki. A hagyományok továbbélésének mély kulturális gyökerei vannak, gyakran racionális családi döntés következménye, és/vagy az egyének prioritásait tükrözi. A külső - főként gazdasági - tényezők által erőltetett 
szerepváltozást a nők és férfiak többsége nem fogadja el, annak ellenáll. Ismert, hogy főként az iskolázott, városi, fiatal családokban tapasztalható átrendeződés a családon belüli munkamegosztásban. A külső kényszerből vállalt szerepcserében férfiak és nők nehezen találják meg a helyüket; a szerepbizonytalanság káros következményei az emberi kapcsolatok, a szocializáció, a családi funkciók és a párkapcsolati problémákban, szexuális zavarokban jutnak kifejezésre (Lux, 1982). Világszerte emelkedik a társtalan, magányos emberek tömege.

A nők és férfiak komplementer szerepének lazítása társadalmi és egyéni szempontból nem tűnik eredményesnek, nem lettek az emberek sem hatékonyabbak, sem boldogabbak. A kényszerek ezúttal sem célravezetők, ebben a kérdésben is a párok döntési kompetenciáját célszerű meghagyni. A döntésük megvalósításához szükséges feltételek kialakítása segítheti az egészséges családi és társadalmi kohézió megteremtését. Kérdés, hogy a fogyasztói társadalomban szükség van-e jól működő családokra, vagy inkább atomizált, könnyen manipulálható tömegre? A gyakorlati tapasztalatok arra engednek következtetni, hogy a fogyasztói társadalmat mozgató hatalom nyomására erre mozdul a világ.

\section{GÉlOK ÉS ESZKÖZÖK: ZAVARKELTÉS DIREKT VAGY INDIREKT, SZÁNDÉKOLT VAGY NEM SZÁNDÉKOLT FORMÁBAN}

A gender ideológia nem tudatlanság terméke, hanem komplex, célirányos, tudatos rendszert alkot. A „nem bináris” nemre épít, a gendert nemi identitásként értelmezi, és társadalmiként interpretálja, hogy a szocializáció folyamatában normává tegye a „nem-bináris” (biológiai és társadalmi) létet. A szocializációt gender semlegesként javasolja, fellazítva a hagyományos, a társadalom működéséért és a nemzet fennmaradásáért felelős szerepmodelleket. Napjainkra a gender olyan „hamis fogalommá” vált, olyan ,jelentéshatalmi fegyver”, amely „mesterséges, hamis valóság létrehozására alkalmas” (Bogár, 2020; kiemelés: KK.). Sőt, „az emberiség utolsó identitásháborúja” zajlik napjainkban....”az egész gender.....azt jelzi, hogy az ember legvégső, legmélyebb önazonosságának kulturálisan is, meg az emberi fizikai testének, az önazonosságának a szétverése zajlik.” (Bogár, 2021; kiemelés: KK.)

\section{A nemzet fennmaradása, mint cél}

Egy nemzet fennmaradásának feltétele a létszámbeli gyarapodás, valamint egyedei fizikai és szellemi egészségének biztosítása, kultúrájának ápolása, ami visszahat a fizikai és szellemi egészségére. Történelmileg bizonyított tény, hogy a nemzet tartópillére a nőre és férfira épülő hagyományosnak nevezett családmodell. Minden olyan törekvés, ami ezeket a feltételeket rombolja, a nemzet fennmaradását lehetetleníti el. 


\section{JEGYZETEK}

1 A tanulmány alapgondolatainak rövid változata megjelent: Gender és nemzet. Magyar Hirlap, 2020. november 20. https://www.magyarhirlap.hu/velemeny/20201120-gender-es-nemzet

A kézirat lezárásának dátuma: 2021. március

2 A hivatkozásokat csupán példaként említem. A hatalmas szakirodalom teljes körủ feltüntetése meghaladja a tanulmány célját és kereteit.

3 Eredeti kiadás éve 1949.

4 Gender is defined as the socially constructed roles, behaviours, activities and attributes that a given society considers appropriate for women and men." (Council of Europe I/3, 2011)

5 Ismertek olyan álláspontok, melyek a megoldás keresését, javaslatok megfogalmazását nem tekintik a tudomány feladatának. Véleményem szerint az öncélú tudomány társadalmilag haszontalan.

6 Hazai legjelesebb képviselője dr. Tamási Erzsébet.

7 Az Elvált Apák Érdekvédelmi Egyesületének jelenlegi elnöke dr. Hegedűs István. „Az egyesület célja: - harmonikus családi életet támogató közfelfogás erősítése, - támaszt és segítséget nyújt a gyermeküktől különélő édesapáknak és gyermekeiknek. A kapcsolattartás megszakadása eseten segíti kapcsolatuk helyreállítását, - a jelenleginél kiegyensúlyozottabb családjogi törvény és joggyakorlat szükségességének elfogadtatása a társadalomban, egyenlő szülöi felügyeleti jog biztosítása mindkét szülő részére, - kapcsolat hasonló célú nemzetközi szervezetekkel, - ingyenes jogi tanácsadás. Forrás: http://elvaltapak.hu/ Letöltés: 2021-01-26.

8 Bíró Dávid a radikálfeminizmushoz hasonló hibát követett el kérdésfelvetésében. Azt a tényszerú megfigyelést, miszerint a hagyományos szerepfelosztás módosulása - a férfiak térvesztése a közszférában, kizárólagos szerepük elvesztése a családfenntartásban, a nők térnyerése a gazdaságban - a férfiak számára egészségi problémákat okozhat és hozzájárul a férfiak halandóságához, kizárólag a nők rovására írta. Holott a szerepváltozásoknak társadalmi háttere van, a szerepcsere okozott problémák társadalmi eredetủek, mindkét nemet érintik, megoldásuk csak a társadalom segítségével, közreműködésével lehet hatékony. Az egyénre, a másik nemre hárított felelősség csupán a nemek szembeállítására alkalmas, mint ahogy teszi azt a radikálfeminizmus és a férfimozgalom radikális szárnya.

9 Forrás: http://www.ferfihang.hu/2011/10/19/lapindito-koszonto/. Letöltés: 2014-02-22. Jelenleg nem található. A lap mára jelentősen bővített profillal múködik: https://www.ferfihang.hu/

10 A szakirodalmi bőség szinte áttekinthetetlen.

11 „,... biológiai nem társadalmi konstrukció, amit egy kulturális autoritás - „»'orvos' «” - erőltet ránk születésünkkor, pusztán külső jegyeink alapján.” (Király, 2015) Vagy „,a társadalom hatalmi struktúrái kényszerítik rá a csecsemőkre." (Laky, 2019)

12 A nemi diszforiát korábban „nemi identitászavarnak” nevezték.”, ami mentális betegség képzetét jeleníti meg. Ezért az Amerikai Pszichiátriai Társaság a „Mentális rendellenességek diagnosztikai és statisztikai kézikönyvé-ben " (2013) nem tekinti betegségnek, az állapotot nemi diszforiának nevezte át. Forrás: https://www.greelane.com/hu/tudom $\% \mathrm{C} 3 \% \mathrm{Al}$ ny-tech-math $/ \mathrm{t} \% \mathrm{C} 3 \% \mathrm{Al}$ rsadalomtudom $\% \mathrm{C} 3 \% \mathrm{Al}$ nyok/gender-dysphoria-4164855/. Letöltés: 2021-02-11.

13 Részletes elemzését lásd a tanulmányban.

14 Különbségek teszek a „társadalom” és a „nemzet” fogalom között. A társadalom az adott intézményi keretek között együtt élő emberek csoportja. A nemzet ennél több: az együtt élő emberek összetartozása a közös nyelv, a közös történelem és közös kultúra tisztelete, az együvé tartozás tudata a nemzeti elkötelezettség talaján.

15 Részletes elemzését lásd Benda-Báger, 2019.

16 Felületes szemlélés talaján akár mulatságosnak is tűnhet az Alaptörvény legújabb módosítása, miszerint az anya nő, az apa férfi. A módosítás igényét az az értékromboló tendencia megjelenése váltotta ki, ami szétzilálja a nemzet alapját képező hagyományos családok rendszerét. 


\section{FELHASZnÁLT irodalom}

Beauvoir, Simone de (1969): A második nem. Gondolat Könyvkiadó, Budapest, 575.

Benda József - Báger Gusztáv (szerk. 2019): Fövőnk a gyermek. Adalékok a népességgyarapodás társadalmi programjához I. Veszprémi Humán Tudományokért Alapítvány, 430.

Bíró Dávid (1982): A teremtés koronái és a gyengébb nem. Valóság, 9. sz. 62-70.

Bogár László (2020): Gender avagy a jelentés-hatalmi háború. https://www.youtube.com/watch?v=LCLhtmG7kAQ. Letöltés: 2020. 10.31.

Bogár László (2021): Háttérkép. Hír Tv, 2021. február 18. https://hirtv.hu/hatterkep/hatterkep-az-alapveto-tortenelmi-kulonbseg-a-jobboldal-es-a-baloldal-kozott-2517096

Buda Béla (1985): Női szerep - női szocializáció - női identitás. In Koncz Katalin (szerk.): Nớk és férfiak. Hiedelmek, tények. Magyar Nők Országos Tanácsa - Kossuth Könyvkiadó, Budapest. 93-110.

Chrisler, Joan C. - Lamer, Sarah A. (2016): Definitions of Gender. The Wiley Blackwell Encyclopedia of Gender and Sexuality Studies. 21 April.

Czeizel Endre (1985): A nők biológiai „természete” és társadalmi lehetőségei. In: Koncz Katalin (szerk.): Nớk és férfiak. Hiedelmek, tények. Magyar Nők Országos Tanácsa, Kossuth Könyvkiadó, Budapest. 21-50.

Council of Europe (2011): The Council of Europe Convention on preventing and combating violence against women and domestic violence (Istanbul Convention). https://www.coe.int/en/web/gender-matters/council-of-europe-convention-on-preventing-and-combating-violence-against-women-and-domestic-violence\#I. Letöltés: 2020-10-08.

Csaba György (1985): A nők biologikuma és társadalmi szerepvállalása közötti ütközések és azok következményei. Koncz Katalin (szerk.): Noók és férfiak. Hiedelmek, tények. Magyar Nők Országos Tanácsa, Kossuth Könyvkiadó, Budapest. 51-67.

Dr. K.A. (2018): A nemi identitás biológiai alapjai. http://otszonline.hu/cikk/a_nemi_identitas_biologiai_alapjai (Letöltés: 2021-02-11)

Fodor Gábor (2020): Csörte. Hír TV, december 23. https://hirtv.hu/csorte/csorte-a-politikanak-az-dolga-egy-demokraciaban-hogy-a-tobbseg-erdekeit-kifejezesre-juttassa-2513949 (Letöltés: 2021-02-11)

Hunyadi György - Nguyen Luu Lan Ahn (szerk.) (2001): Sztereotípiakutatás, hagyományok és irányok. ELTE Eötvös Kiadó, Budapest, 499.

Gender, Work and Organization, Blackwell kiadó

Gerő András (2020): Csörte. Hír TV, december 23. https://hirtv.hu/csorte/csorte-a-politikanak-az-dolga-egy-demokraciaban-hogy-a-tobbseg-erdekeit-kifejezesre-juttassa-2513949 (Letöltés: 2021-02-11)

G. Fodor Gábor (2020): Csörte. Hír TV, december 23. https://hirtv.hu/csorte/csorte-a-politikanak-az-dolga-egy-demokraciaban-hogy-a-tobbseg-erdekeit-kifejezesre-juttassa-2513949

Green, Richard (2010): Robert Stoller's Sex and Gender: 40 Years On. Archives of Sexual Behavior, 39. évf. 6. sz. December, 1457-1465. p.

Illés-együttes (1972): A szó veszélyes fegyver. https://songbook.hu/lyrics/5089/a-szo-veszelyes-fegyver, Letöltés: 2020. 10. 31 .

Király András (2015): A nagy genderszótár: minden, sőt, egy kicsit annál is több, amit az idejét múlt bináris férfinő meghatározáson túl tudnod kell. !!444!!! Életmód, június 11. https://444.hu/2015/06/11/a-nagy-genderszotar-minden-sot-egy-kicsit-annal-is-tobb-amit-az-idejet-mult-binaris-ferfi-no-meghatarozason-tul-tudnod-kell Letöltés dátuma: 2021.07. 04.

Koncz Katalin (szerk.) (1985): Nớk és férfiak. Hiedelmek, tények. Kossuth Könyvkiadó, p. 270.

Koncz Katalin (2020): Gender és nemzet. https://www.magyarhirlap.hu/velemeny/20201120-gender-es-nemzet. Letöltés dátuma: 2021.07.04.

LaFont, Suzanne (2015): Gender. The International Encyclopedia of Human Sexuality. 20 April.

Laky Zoltán (2019): Tényleg elismerte a genderelmélet atyja, hogy kitalálta az egészet? Nem, de igény lenne rá. Válasz online, 11. 12. https://www.valaszonline.hu/2019/11/12/christopher-dummitt-gender-leleplezes-hatter/. Letöltés: 2021-02-12

Lux Elvira (1982): Női szerepek a szexuálpszichológus szemével. Minerva, Budapest, 324. 1. 
Macey, Marie (1995): The moment of municipal feminism: gender and class in 1980s local government. Critical Social Policy, No. 44/45. 126-146. 1.

MTA Társadalomtudományi Kutatóközpont (é. n.): Biológiai nem és társadalmi nem. https://www.tk.mta.hu/biologiai-nem-es-tarsadalmi-nem. Letöltés: 2020. 09.11.

Richards, Christina (2016): Third Genders. The Wiley Blackwell Encyclopedia of Gender and Sexuality Studies. Hoboken, NJ: Wiley-Blackwell.

Rosser, Sue V. (1992): Are the feminist methodologies appropiate for the natural sciences and do they make a difference? Women's Studies International Forum, vol.15., No. 5-6, 535-550.

Sípos Írisz (2010): Gender-ember avagy férfi és nő? Vigilia, 74. évf. július. https://docplayer.hu/27881579-Genderember-avagy-ferfi-es-no.html. Letöltés: 2021-02-03.

Stoller, Robert J. (1984): Sex and Gender: The Development of Masculinity and Femininity. Karnac Books, 401.

Sullerot, Evelyne (Szerk.) (1983): A női nem. Tények és kérdöjelek. Gondolat Könyvkiadó, Budapest, 5671.

Transvanilla Transznemü Egyesület: https://transvanilla.hu/genderqueer. Letöltés: 2020.-11-20.

Tong, Rosemarie (1992): Feminist Thought. A Comprehensive Introduction. Routledge, London, 3051

Warren, Karen J. (1994): Ecological Feminism. Routledge. London, New York, 2091. 